\title{
Expectations of FINEP and São Paulo Anjos Agents Concerning the Use of Venture Capital in Technology-Based Small and Medium Enterprises
}

\author{
Marcela Barbosa de Moraes', Antonio Lobosco², Edmilson Lima ${ }^{3}$
}

\begin{abstract}
This work aims at providing a better understanding of the relations of venture capital agents with entrepreneurs of small- and medium-sized technology-based firms by studying their expectations. The study used qualitative, multiple-case research method, predominantly following the precepts of Eisenhardt (1989). Data collection was done through analysis of documents and semi-structured in-depth interviews with FINEP and São Paulo Angels (SPA) agents. Data analysis followed intra-and inter-case steps (Miles and Huberman, 1994). The results indicate that FINEP agents' expectations for entrepreneurs who benefit from venture capital are compliance with deadlines established, development of the items specified in the approved project (prototype, product, etc.), generation of innovations that benefit society, and development of business management knowledge and practice. SPA agents' expectations are that entrepreneurs have high motivation and passion in relation to the business, work ethically and according to the law, and maintain a very good relationship with SPA agents to achieve solid results.
\end{abstract}

Keywords: venture capital; finep; são paulo anjos; small and medium enterprises; technology-based enterprises.

Graduate Program in Administration, Universidade Nove de Julho (UNINOVE),Av. Francisco Matarazzo, 6 I 2 - Água Branca - São Paulo - SP - Brazil,0500I-100. 'E-mail: marcelabmoraes@gmail.com. ${ }^{2}$ antoniolobosco@hotmail.com.

3edmilsonolima@gmail.com. 


\section{Introduction}

Technology-based companies contribute to the development of countries through major socioeconomic benefits such as support for the industrialization process, technological development, and jobs creation (Santos et al., 2005; Moraes, Lima and Lobosco, 20I I; Li, Qian and Qian, 20I2).Thus, these companies are an important focus of attention and support by the government and societies in general. Many countries offer specific programs and policies to encourage financial, technological, and administrative support to emerging technology-based companies as a way of developing their competitiveness (Berté et al., 2008).

Another important factor, not only for technology-based companies but also for traditional ones, is the role of entrepreneurs in the creation and management processes in new businesses. For Schumpeter (1982), entrepreneurs are producers who initiate economic change and, if necessary, educators of consumers for the consumption of the innovations they create. As such, entrepreneurs promote creative destruction - i.e. the replacement of old products and consumer habits with new ones. With this concept, Schumpeter (1982) describes the process of economic development and the aspects that involve the innovative spirit of entrepreneurs. Creative destruction, according to him, is related to the dynamics of goods production and circulation, intrinsic processes of capitalist economic life. Because these processes are constantly changing, they promote the destruction of old production structures and their replacement with new ones, based on the innovations that arise. This permanent creative destruction is the essence of capitalist economic development, according to the author.

Incentives for innovative entrepreneurs - offering of qualified human resources and technological and financial resources - aid in the creation and development of technology-based companies. One of the aspects mentioned above, and a highly relevant one, is that of financial resources for the development of emerging technology-based companies. In Brazil, among the principal venture capital investors for these companies, is the Financiadora de Estudos e Projetos - FINEP (Studies and Projects Financer), whose mission is to promote economic and social development in Brazil through public financial support for science, technology, and innovation in companies, universities, technology institutes, and other public and private institutions. In addition are the angel investors, who also play an important role in providing investments.

Considering the importance of encouraging the development of technology-based small and medium enterprises (SMEs) with technology funding programs, this work aims to generate a better understanding of the relationships of angel investors and FINEP with entrepreneurs who are financed by these organizations by studying the expectations of these funding body agents.

\section{Conceptual Framework}

Technology-based companies are organizations focused on activity and competitive differential based on the technology of processes and products; these companies differ from traditional businesses in their need for faster response times to meet market demands and competition, which forces them to be more agile and organizationally flexible (Rothwell and Dodgson, 1989; Li, Qian and Qian, 20I2). Technology-based companies typically have a higher growth potential than nontechnology-based companies, which benefits the economic and technological development in a country (Markusen, Hall and Glasmeier, 1986; Meyer and Roberts, 1988).

In Brazil, the growth of entrepreneurship is occurring in parallel with the process of privatization of large state institutions and the opening of domestic markets to foreign competition. In this country, development agencies consider entrepreneurs as key to economic growth and generation of innovations and jobs. Political and economic stability has increased the level of investments in the country, promoting the creation of new businesses and fostering emerging and established technology-based companies. The consolidation of venture capital funding and the role of angel investors are also becoming reality, encouraging the establishment of optimistic scenarios for the coming years.

In Brazil, and the rest of the world, the need for and the difficulty in making investments for entrepreneurial and innovation-driving activities have been much discussed. Establishing a technology-based company depends on a number of factors. One of the most important is the capital required to start activities and enable it to compete in a highly competitive and selective market.

\section{Characterization of Technology-based Companies}

Technology-based companies play an important role in the economic and social development of a country, contributing to innovations in products with high market potential, creating skilled jobs, stimulating the process of science and technology, and strengthening relations between various economic agencies and sectors (Lima, 2005; Moraes et al., 2010). These companies use innovative technologies, can have a high proportion of spending on research and development, employ a high proportion of technical-scientific and engineering personnel, and serve specific markets that probably would not otherwise be served (Ajagbe et al., 20I2).

Costa (2005) points out that the area of Science and Tech- 
nology (S\&T) uses a restrictive concept of "technologybased company". For S\&T, a technology-based company is one whose innovation is of a technological nature and whose primary knowledge exploited in production is from the field of technology. However, the author mentions that in the world of innovation in the knowledge society, innovative knowledge may be of both a technological nature as well as an accumulated knowledge of the product, process, or market. The Associação Nacional de Entidades Promotoras de Empreendimentos de Tecnologias Avançadas (ANPROTEC) (National Association of Agencies Promoting Advanced Technology Entrepreneurship) defines a technology-based company as an enterprise whose production is founded on the development of new products and processes, based on the systematic application of scientific and technological knowledge and the use of advanced pioneering techniques (ANPROTEC, 2002). The availability of technology in societies is therefore one of the important benefits that technology-based companies provide.

For the Organisation for Economic Co-operation and Development (OECD, 20II), one of the most important indicators for classifying the activities of companies by technological intensity is the level of R\&D investment plus the application of resources in technology incorporated in intermediate goods and capital goods. From this perspective, the OECD (20I I) classifies activities into four groups according to technological intensity companies:

- High-technology industries: aircraft and spacecraft; pharmaceuticals; office, accounting and computing machinery; radio, TV, and communication equipment; medical, precision and optical instruments

- Medium-high-technology industries: electrical machinery and apparatus; motor vehicles, trailers and semitrailers; chemicals excluding pharmaceuticals; railroad and transport equipment; machinery and equipment

- Medium-low-technology industries: construction and repair of ship and boats; rubber and plastics products; coke, refined petroleum products, and nuclear fuel; other non-metallic mineral products; basic metals and fabricated metal products

- Low-technology industries: manufacturing, recycling; wood, pulp, paper, paper products, printing and publishing; food products, beverages and tobacco; textiles, textile products, leather and footwear

Considering the IBGE and SEBRAE (Brazilian Institute of Geography and Statistics and Brazilian Support Service for Micro and Small Enterprises) definition criteria for small business and the particularities of the technological activity, small technology-based companies are industrial firms employing 20 to 99 employees, or commercial and service companies with 10 to 49 employees; medium technology- based companies are industrial firms employing 100 to 499 employees, or commercial and service companies with 50 to 99 employees, which are characterized by systematic use of techno-scientific knowledge and committed to the design, development, and production of new products and/ or processes (Moraes et al., 2010). Mendes, Mecenas, and Toledo (2004) conclude that, in Brazil, these firms are heavily concentrated in four economic sectors: medical equipment and instruments and precision automation, information technology, electronics and communication, and the chemical industry.

Spencer (2003) explains that the characteristics of technology-based SME products are narrow scope of use, short life cycle, high development cost, rapid obsolescence, small domestic market demand, and low sales volume, market, and global competition. An important feature for these companies is high vulnerability to changes in the environment in which they operate and, therefore, an increased need for adaptability to such changes (Moraes et al., 2010). This is primarily because of high resource constraints (financial, personnel, etc.) in comparison to large firms, which is a key distinguishing feature of SMEs in general (Martin and Staines, 1994; Welsh and White, 1981). The elevated risk relative to innovative activities, an inherent factor in technology-based SMEs, is one of the elements that differentiate them from nontechnology-based SMEs. Product innovation often generates uncertainties because the speed that such innovation will be disseminated and demanded by the market, the new technological challenge that will arise, the technological standard which customers will adopt, and the changes in their needs are normally unknown (Carvalho et al., 2000).

\section{Venture Capital for Technology-Based Companies}

Financing for companies may have distinct configurations, such as capitalization, loans, advances, grants, and donations. For the purposes of this article, "venture capital" is used more narrowly to designate one type of financing for technology-based companies. Granting venture capital, according to Santos et al. (2005, p. 46-47), covers a promising and uncertain activity that brings together investors and entrepreneurs: an activity in which the investor takes a risk with the profits or losses of the company through long-term investments and with no guarantees of receiving back the capital because the company is not obliged to reimburse if it goes bankrupt.

Additionally, venture capital is a type of investment in which investors apply resources to companies with expectations of rapid growth and high profitability (FINEP, 200I). The investment is given to the company via acquisition of shares or participation rights, such as convertible debentures and warrants. This form of operation is different from conven- 
tional financing and implies, besides the input of financial resources in the company, a shared administration between the entrepreneur and the investor, who uses this expedient to gain greater assurance that the investment will be used as programmed and that the company will develop satisfactorily to achieve the expected returns. According to Costa (2005), funding sources for companies may be of three types: (a) non-reimbursable funds for research and development R\&D, (b) venture capital: a form of capitalization with which the investor puts money in the company buying a share of the company, (c) normal financing, a loan that is commonly granted to individuals to develop business activities.

For venture capital, Santos et al. (2005, p. 53-55) distinguish four types:

I. Seed capital is financing for an idea or project to establish a company. In this type, the entrepreneur is willing and able to make the project viable (to develop a prototype, to research or to refine the project) in economic terms with the creation of a new business.

2. Startup financing is financing for establishing the company. In this situation, usually the prototype has already been developed, the market researched, and the project designed - it may even include seed capital.

3. Development financing is a kind of venture capital for new businesses to move forward beyond the founding phase. Normally, the company is already producing, but its financial state has not surpassed the breakeven point. There is no profit to ensure self-financing and growth.

4. Mezzanine is financing for when a company already has credibility and requires financial support to launch a new phase of growth.
These elements are clearly identified in Figure I and show the types of investors and types of financial contributions for each development stage in technology-based companies. Endeavor (2010) suggests different investment phases in the life cycle of technology-based companies. For start-ups, venture capital investments usually come from angel investors and intellectual property investors. In the company's "childhood", resources come from angel investors, venture capital, and research grants. In the "adolescence" and "maturity" stages, the principal sources of funding are venture capital and private equity.

According to FINEP (200I), venture capital is primarily indicated for technological start-ups because of the characteristics of this type of financing: it does not demand entrepreneurs' guarantees; it does not demand cash disbursement in the early stages of the business concerning interests and depreciation payments; it is operationalized by venture capital funds that provide active monitoring and administrative support, critical for the success of start-ups; and it provides investors a return consistent with the higher risk associated with technology-based companies. Venture capital applies to capitalization phases preceding initial public offering (IPO) and accompanies the growing needs of the company's financial resources, balancing risk and return, as shown in Figure 2.

According to IBGE (2005), the challenges related to venture capital are some of the obstacles to innovation mentioned by business leaders in Brazil in a survey conducted from 2003 to 2005. This is illustrated in Chart I, in which business leaders indicate the obstacles related to venture capital such as the high costs of innovation and the scarcity of funding sources.

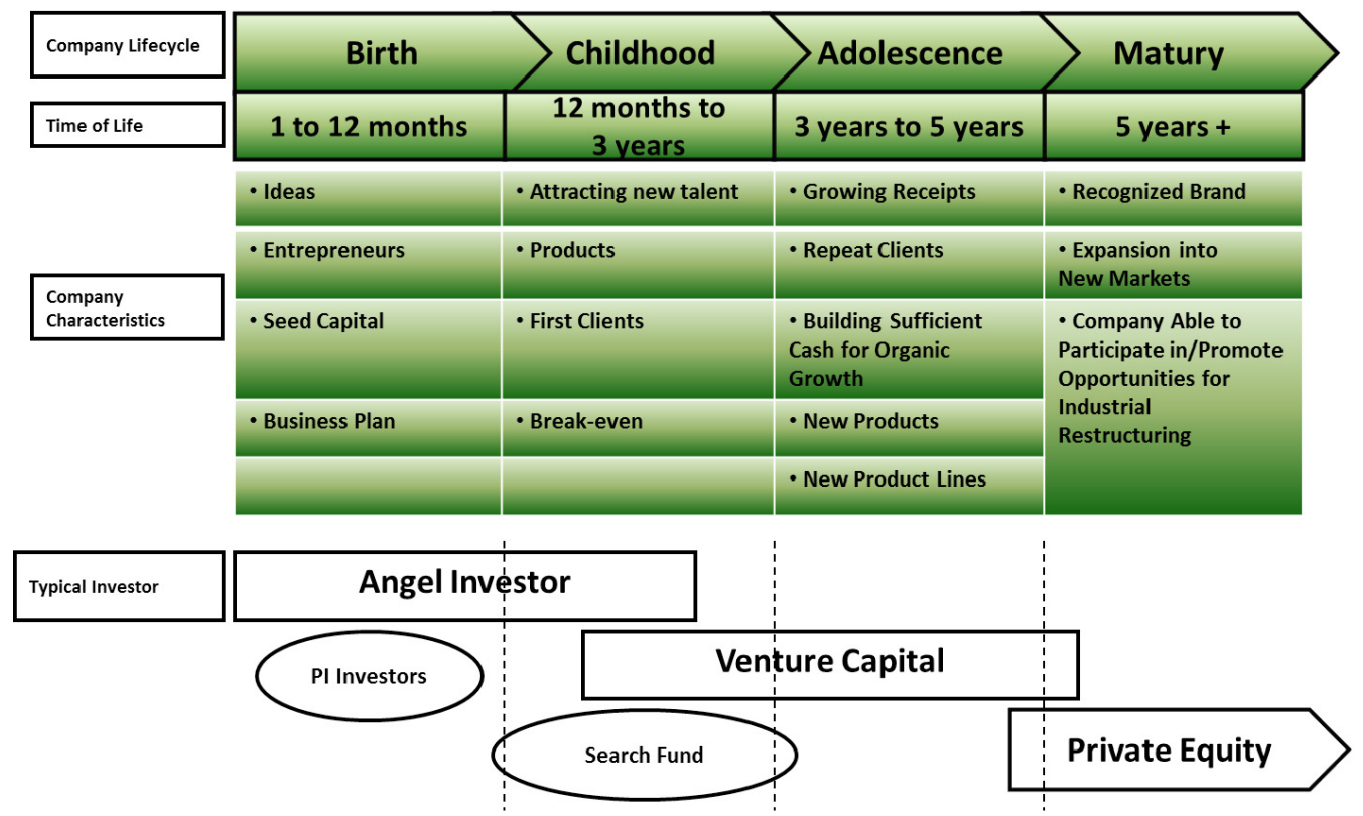

Figure I. Financing Sources for Each Development Stage in Technology-based companies. Data from Endeavor (20I0).

ISSN: 07I 8-2724. (http://www.jotmi.org)

Journal of Technology Management \& Innovation (c) Universidad Alberto Hurtado, Facultad de Economía y Negocios. 
Despite the scarcity of financial resources for companies to innovate in a highly competitive and globalized environment, emerging countries pursue a strategy of economic growth that depends on entrepreneurship and technological innovation (Botelho et al., 2006). However, it is hoped that both do not rely solely on funding coming from state bodies and agencies. The financing mechanisms for science and technology projects currently available in Brazil based on the multiannual plan policies (PPA) of the Brazilian federal government are the sectorial funds and the Industrial, Technological, and Foreign Trade Policy (PITCE), which are operationalized by FINEP, the National Council for Scientific and Technological Development (CNPq), and the Coordination for Improving Higher Education Personnel (CAPES). In addition, there are the research support foundations in some Brazilian states that fund scientific and technological initiatives.

Considering the large number of start-ups in the country, thanks to national entrepreneurship that emerges with higher rates of business creation than in other countries, investments by organizations and state agencies alone are not sufficient to meet the investment needs of Brazilian new businesses. One measure of initial entrepreneurial activity in countries is the Total Early-stage Entrepreneurial Activity (TEA). According to the GEM study, the TEA is the proportion of people between 18 and 64 years old who head businesses that have existed for less than 42 months. Brazil occupies sixth place in the TEA ranking among countries, according to efficiency-driven criteria - countries in which the industrial sector develops more, and institutions appear to support industrialization and seek higher productivity through economies of scale (Bosma and Levie, 2010).

Angel investors can supply part of the financing needs for start-ups and companies up to three years old not covered by state resources and funding agencies. They are a private funding alternative that may provide more than just financial resources. They may offer advantages such as sharing market experience and networking, which complement the company's administration.

\section{Angel Investors}

The expression "angel investor" originated in the United States in the early twentieth century to identify investors who made risky investments in Broadway theater productions. The word "angel" is a theater term and bears no religious connotation (Calvosa and Freitas, 2008). Today the term refers to high net-worth individuals who invest in the start-up growth of companies. In the United States, these are generally accredited investors according to the rules of the Securities and Exchange Commission (SEC), the American equivalent of the Comissão de Valores Mobiliários ( CVM) in Brazil.

The main objective of an angel investor is to profit from the investment. Even so, the angel capital injected in a company's start-up phase furnishes the resources required to take the company to a development level of self-sustaining growth, leading it to the point at which it becomes competitive and achieves the potential and maturity needed to receive other financial contributions, such as venture capital and private equity (Madill, Haines Jr and Riding, 2005).

The expression "angel investor" is still little known in Brazil. However, this actor's participation in innovative investments is growing in the country, considering that SMEs, especially technological ones, have difficulty in finding investments due to problems such as lack of a solid customer base, minimal management experience, and low disclose (Calvosa and

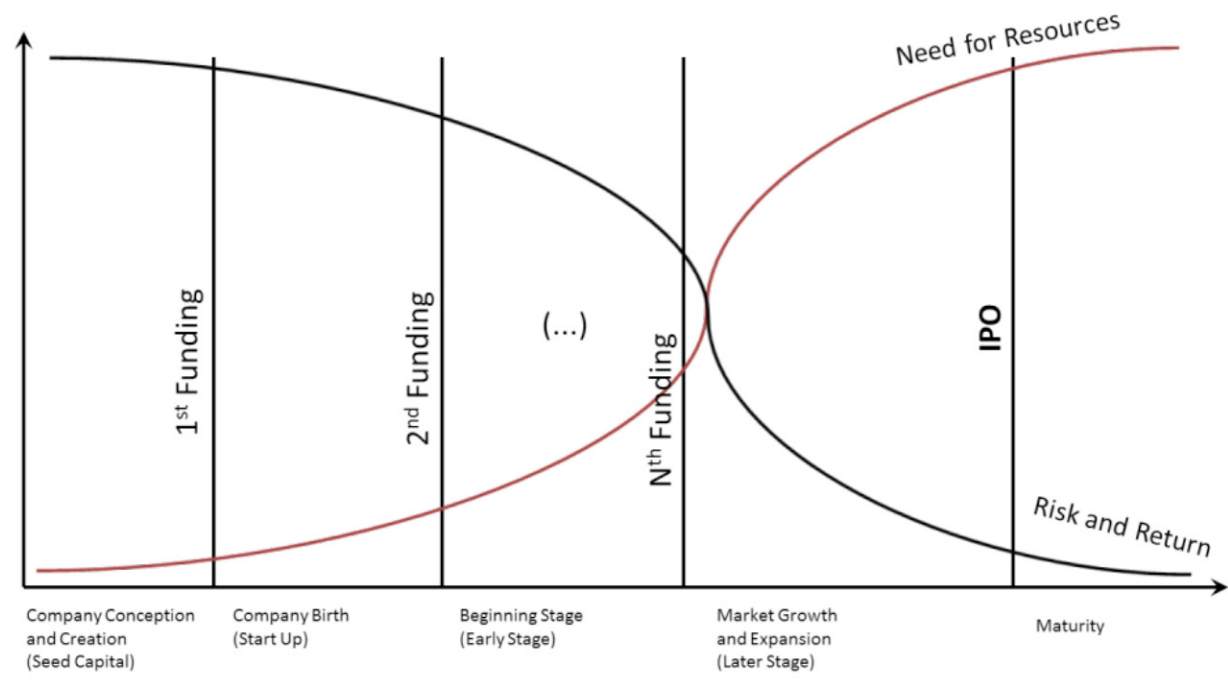

Figure 2. Needs for Resources and the Balance between Risks and Return on Investment. Data from FINEP (200I).

ISSN: 07I 8-2724. (http://www.jotmi.org)

Journal of Technology Management \& Innovation (c) Universidad Alberto Hurtado, Facultad de Economía y Negocios. 
Freitas, 2008). In exchange for capital and dedication to the project, the angel receives equity interest and may also participate in management - e.g. take a seat on the board of directors. In some cases, though, such involvement is informal. This type of investor helps to fill the gaps in a growing market, providing funding and transferring management knowhow. Angels seek innovative projects with high potential for growth and profitability, requiring professional and qualified assistance, and usually not considered by state organizations and agencies.

\section{Methods}

We chose to use a qualitative, exploratory, descriptive research method to examine and define the expectations of FINEP agents and São Paulo Angels (SPA) for the technology-based SMEs in which they invest. Especially in Brazil, the SME risk capital theme has little specific theoretical-conceptual basis from previous empirical studies. To develop a robust study, we used the multiple case study methodology, following the recommendations of Eisenhardt (1989) and the details on using these recommendations described by Lima $(2010,2012)$. The proposed method was selected to generate a descriptive and explanatory understanding of the phenomenon in question in a predominantly inductive manner, from multi-case qualitative research. The approach presented by Eisenhardt (1989) is based largely on the methodological proposals of grounded theory (Glaser and Strauss, 1967).

According to Eisenhardt (1989), case study can be applied to highlight or to comprehend the dynamics of parallel events, primarily contemporary ones. The author also points out that case studies may combine various techniques of data collection and analysis - such as studies of historical data and archives, questionnaires, interviews, and observations - and can take on quantitative, qualitative, or quantitative/ qualitative perspectives. In addition, the author states that the choice of cases is a very important aspect because it defines the characteristics of the study design. In our multicase study, cases were intentionally chosen based on the contributions they could deliver to the study - i.e. the study sample is characterized as theoretical and intentional (Lima, 2010, 2012).

For data collection, we adopted a semi-structured, in-depth individual interview. This qualitative technique allowed exploring the subject through seeking information, experienc-

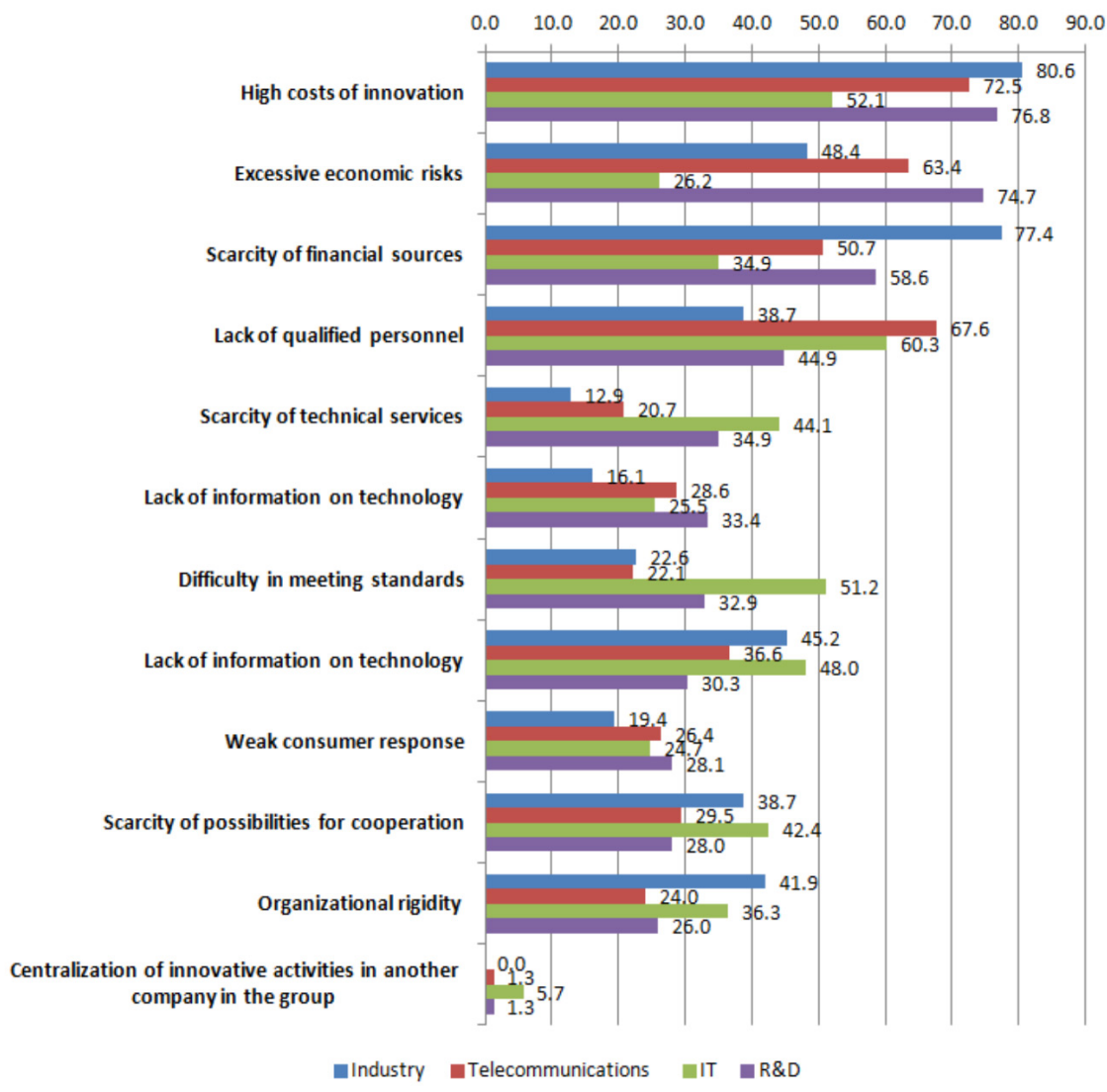

Chart I. Obstacles to Innovation in Industry and Service Activities in Brazil - from 2003 to 2005. Data from IBGE (2005)

ISSN: 07 I8-2724. (http://www.jotmi.org)

Journal of Technology Management \& Innovation (c) Universidad Alberto Hurtado, Facultad de Economía y Negocios. 
es, and perceptions of respondents to analyze and present them in a structured form. It should be noted that the semistructured, in-depth individual interview is a methodology that, based on theories and assumptions defined by the researcher, collects responses from the experience of a source selected for possessing the information required. Four people were interviewed: one FINEP director, one FINEP business prospection agent, one SPA director of project selection, and one SPA consultant board member. On average, the interviews lasted 2.5 hours. Additional data sources include various documents from both organizations as well as their Internet sites.

The data collected in the interviews were analyzed in two stages: intra-and inter-case. Intra-case analysis describes, explains, and generates understanding of what happens in a unique and limited context - i.e. in one case (Miles and Huberman, 1994). This type of analysis that takes each case separately places greater emphasis on conceptual content, which is more important for describing and explaining a given phenomenon (Lima, 2010, 2012). Conversely, intercase analysis describes and explains conceptual contents, processes, and outcomes of a particular phenomenon by comparative analysis of different cases to identify regularities and differences between them regarding data on the phenomenon in question (Miles and Huberman, 1994).

From this perspective, the data were analyzed using Atlas. ti qualitative analysis software. According to Muhr (1995) and Lima $(2010,2012)$, this tool was developed to meet the challenge of managing the large amount of data that is typical in qualitative research, and facilitate data coding and classification.

\section{The Case of FINEP}

FINEP is a public organization under the Brazilian Ministry of Science and Technology (MST). It was created on July 24, 1967, to operationalize the Fundo de Financiamento de Estudos de Projetos e Programas - FFPP (Financing Fund for Research Projects and Programs), created in 1965. Later, FINEP replaced and expanded the role previously played by the Banco Nacional de Desenvolvimento Econômico e Social - BNDES (Brazilian Development Bank) in its Fundo de Desenvolvimento Técnico-Científico - FUNTEC (TechnicalScientific Development Fund), established in 1964 to finance graduate programs at Brazilian universities (FINEP, 20I0).

On July 31, 1969, the federal government established the Fundo Nacional de Desenvolvimento Científico e Tecnológico-FNDCT (National Fund for Scientific and Technological Development) to finance expansion of the S\&T system, with FINEP as its executive office from 197I. In the 1970s, FINEP promoted intense mobilization in the scientific community to fund deployment of new research groups, creation of thematic programs, expansion of S\&T infrastructure, and consolidation of institutional research and graduate studies in the country. It also encouraged dialog between universities, research centers, consulting companies, and service, product and process contractors.

Currently, FINEP's mission is to stimulate economic and social development in Brazil by promoting science, technology, and innovation in companies, universities, technology institutes, and other public and private institutions (FINEP, 20I0). According to the agents interviewed, FINEP provides refundable and non-refundable financing. FINEP support covers all stages and dimensions of the scientific and technological development cycle: basic research, applied research, innovation, and product, service and process development. FINEP also supports nurturing technology-based companies, establishing technology parks, structuring and consolidating research processes, development and innovation in established companies, and developing markets. Respondents indicated that FINEP only funds pre-production stages and does not invest in production expansion. For this type of support, FINEP directs those interested to BNDES.

For start-up technology-based companies, FINEP provides various financing arrangements. One is the Primeira Empresa Inovadora - PRIME (First Innovative Company) program. Created in 2009, it aims to create favorable financial conditions so that a significant number of new companies with high added value may successfully consolidate their initial development phases. PRIME's driving vision is to provide a change in the quantitative and qualitative level of FINEP support programs, including start-up companies from all Brazilian regions.

According to the data obtained from respondents, most start-up innovative ventures present structural weaknesses and various developmental difficulties in their initial phase because entrepreneurs and company founders diverge from the main focus of the business to engage in parallel activities that guarantee their, and their company's, short term survival. PRIME supports companies in this critical birth stage, allowing entrepreneurs to devote themselves entirely to developing innovative and original products and processes and establishing winning strategies for market insertion.

PRIME is based on institutional cooperation agreements between FINEP and decentralized operators to meet startup companies' large demand for resources. Because of the complexity, scope, and inherent costs of infrastructure needed to operate a national program of this scale, there is a clear need for this institutional cooperation between FINEP and regional partners. Decentralized operators are agencies with credibility and proven ability in supporting start-up in- 
novative companies. The principal decentralized operators are: I - in São Paulo: Cietec, Fipase, and FVE/Univap; II - in Minas Gerais: Biominas, Fumsoft, and Inatel; III - in Rio de Janeiro: Coppe/UFRJ, Instituto Gênesis, and BioRio; IV - in Santa Catarina: Celta and Instituto Gene; $\mathrm{V}$ - in Rio Grande do Sul: PUC/Raiar and Faurgs/CEl; VI - in Amazonas: Cide; VII - in Paraíba: Parque Tecnológico da Paraíba; VIII - in Pernambuco: Cesar; and IX - in Sergipe: Cise.

Respondents explained that this type of financing is for start-up companies that are less than 24 months old with a high level of innovation in their products or services and business plans that indicate clear growth potential and a set of achievable challenges and goals. PRIME candidates must attend a training program in entrepreneurship and business management specifically designed for the program. As the interviews reveal, PRIME beneficiaries can also be assisted by other FINEP programs, especially the INOVAR Semente program. This fund arose in 1999, when FINEP began with the creation of INOVAR in partnership with the FUMIN/ BID (a multilateral investment fund supported by the InterAmerican Development Bank - IDB/BID), to support innovative companies via a structured program of venture capital. Thus, in May 2000, INOVAR I was born. Key among its achievements are (I) participation in the creation of the Associação Brasileira de Private Equity e Venture Capital - ABVCAP (Brazilian Association of Private Equity and Venture Capital) - a nonprofit organization that supports the development of long-term investment activity in the country related to private equity, venture capital and seed capital; (2) partnerships with pension funds and nurturing agents for investment funds; and (3) establishment of various forums to bring start-up companies and investors together. In July 2008, INOVAR II began with the goal of promoting actions to consolidate venture capital and private equity activities and contribute to the development of a seed capital industry in Brazil.
INOVAR Semente made its first call for applications in 2006. Over a total of five calls, 48 inscriptions were made by technology-based start-ups requesting venture capital, of which 22 were selected for due diligence. FINEP approved financial support for six of them. FINEP agents' expectations for entrepreneurs who benefit from venture capital are compliance with deadlines established by the institution, development of the items specified in the approved project (prototype, product, etc.), generation of innovations that benefit society, and development of business management knowledge and practice, since the directors have predominantly technical backgrounds. To ensure this, they visit each entrepreneur every six months to verify how the projects are progressing.

\section{The Case of São Paulo Anjos (SPA)}

SPA is a private, nonprofit organization whose mission is to facilitate angel investors' access to start-up companies with growth potential and valuation differential, as well as facilitate entrepreneurs' access to the financial and intellectual capital needed in the early stages of their businesses. SPA was established in July 2007 by a group of professionals interested in applying financial resources in promising businesses in the state of São Paulo. Currently, it has $\mathbf{4 4}$ members interested in investing financial and intellectual capital in start-up companies. Respondents explained that intellectual capital is a result of these members' knowledge, accumulated through their relationships and experiences, and the skills developed and training acquired in various areas such as management and marketing.

Also according to the interviews, SPA adopts an operation model that emphasizes members' active participation. They must be involved in the search for and analysis of projects, share their knowledge with other members, and participate

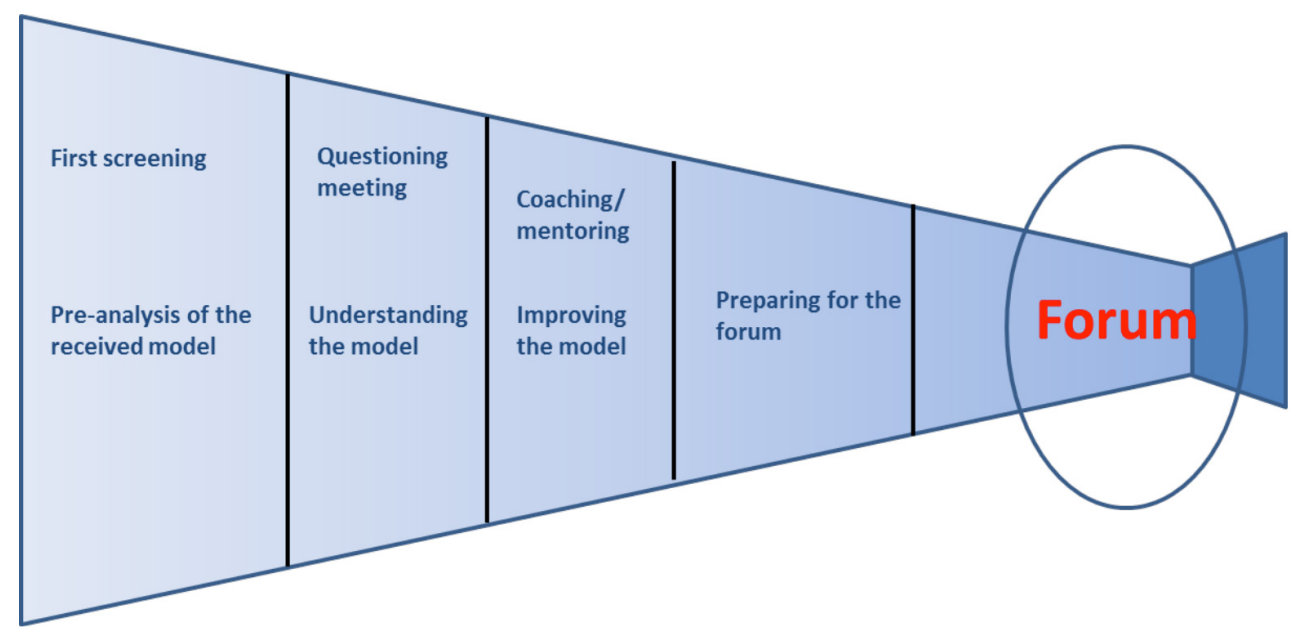

Figure 3. Project Selection Process. Data from São Paulo Anjos (2013).

ISSN: 07I 8-2724. (http://www.jotmi.org)

Journal of Technology Management \& Innovation (c) Universidad Alberto Hurtado, Facultad de Economía y Negocios. 
in investor events and forums. One of the interviewees emphasized that the relationship between members is very strong and reliable, which is important because in the future they may be partners.

Through the collaboration of its members and backing of its supporters, SPA offers:

I. The opportunity among members to benefit from SPA associates' networking

2. The opportunity to benefit from the diversified SPA human and intellectual capital in various activities and internal work processes

3. The possibility of business plan analysis by experienced professionals (the members) through mentoring and coaching

4. Investment opportunities through periodic project presentation forums - restricted to SPA members and guests

5. Conferences and events on topics related to entrepreneurship and angel investment

SPA does not focus on only one particular segment but may have projects directed at industry, commerce, and services. Associate investors seek temporary acquisition of equity interest. They have minority shares, but require a signed agreement that establishes basic rights. There is the expectation of realizing significant capital gains with the sale of shares over a projected timeline. It has, however, a number of selection criteria for considered projects. For a business to receive SPA investment, the criteria are as follows:
- $\quad$ Scale: large growth potential

- Innovation: in management and business and/or technology model

Management team: with prior experience in the project's business segment; not necessarily with a full team

- Exit strategy: an idea of who might buy the company in the future

- Business plan: a relatively complete business plan

- $\quad$ The role of angel investor: providing management and networking assistance

Valuation: meeting the SPA potential for capital investment and levels of financial return sought by SPA associates

Location: company headquarters located in the state of São Paulo

Selection of projects, which are received via the SPA internet site, has four principal stages, as shown in Figure 3.

In the initial stage, first screening, the projects received by the SPA Internet site are analyzed to verify compliance with the selection criteria described above. Those that pass this stage are accompanied by a tutor who assists the entrepreneur in preparing for stage two: presentation and questioning meeting. The tutor is an associate with experience in the project's market and assists in establishing contact between the entrepreneur and associates, partners, and, in some cases, outside entities.

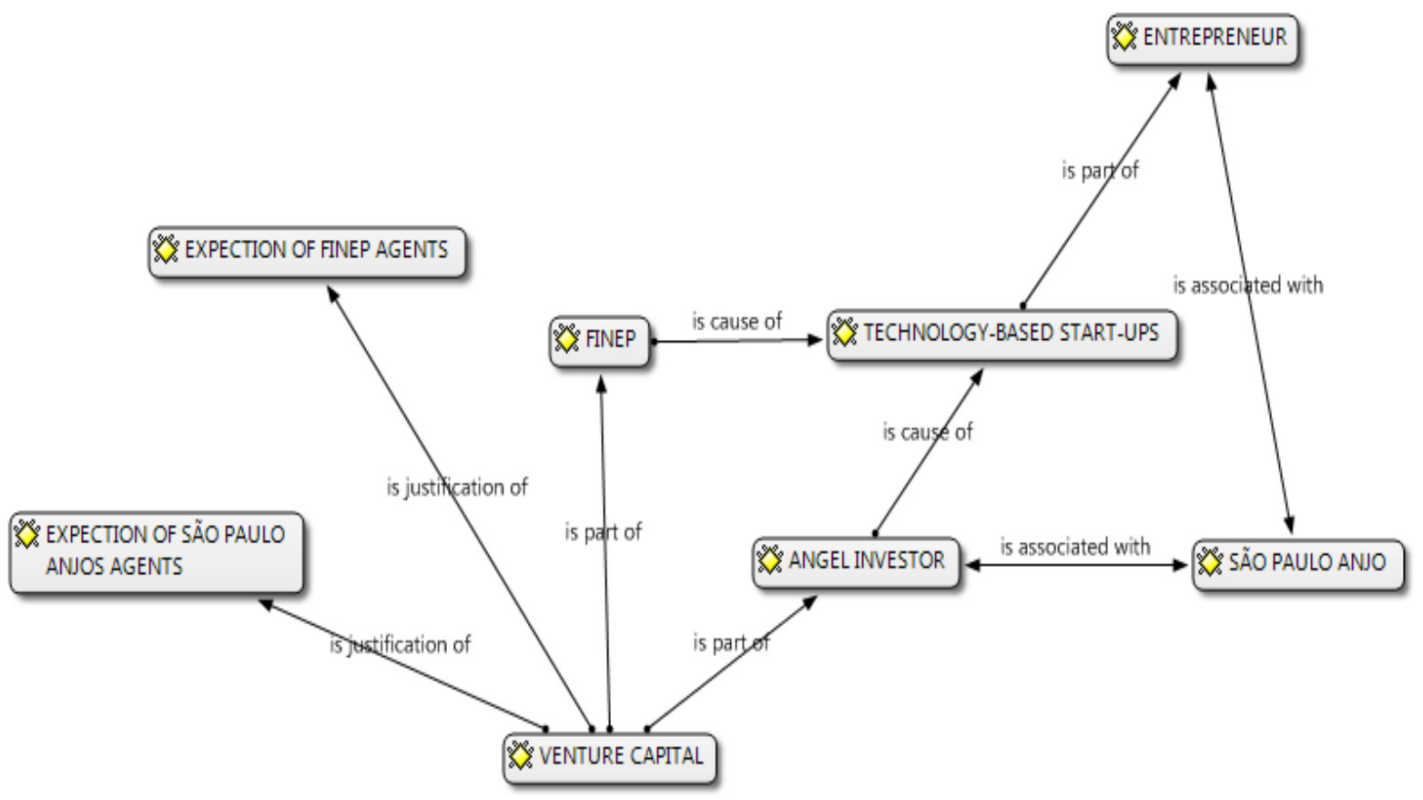

Figure 4.Visual Representation of Agents' Expectations

ISSN: 07 I8-2724. (http://www.jotmi.org)

Journal of Technology Management \& Innovation (C) Universidad Alberto Hurtado, Facultad de Economía y Negocios. 
The third stage involves coaching and mentoring, in some cases offered by an SPA member. A group of associates is formed to express opinions about possible improvements to the business model; these group members and the tutor, however, are not responsible for writing the business plan for the entrepreneur. The fourth and final stage is the preparation for the forum. The entrepreneur receives assistance in developing a twenty-minute presentation for potential investors.

\section{Inter-Case Data Analysis}

To organize and analyze the data collected from interviews and documents, we developed a visual representation (see Figure 4) of the relationships among the concepts identified in the data - codes of analysis, according to the grounded theory nomenclature - as most relevant to achieving the study's objective. Using visual representation for data analysis is a procedure consistent with the analysis recommendations of Miles and Huberman (1994). It was developed with the help of Atlas-ti qualitative data analysis software, useful for treating large amounts of collected data. This system was also used for creation, comparison, and other treatments of the codes presented in Figure 4.

The visual representation codes have the following characteristics:

- Venture capital: This code is related to a type of investment in which investors apply resources to companies with expectations of rapid growth and high profitability. This investment is made through acquisition of shares or participation rights, such as convertible debentures and warrants. Unlike loans, this form of operation implies, besides the input of financial resources, shared management with the entrepreneur, important to ensure the healthy development of young innovative companies (Santos et al., 2005).

- $\quad$ FINEP: This Brazilian organization provides financial resources. Its mission is to promote economic and social development in Brazil by way of public support for science, technology, and innovation in companies, universities, and technological institutes. It does this by offering venture capital.

- $\quad$ Angel investor: This is an agent offering venture capital. He/she helps to fill the gaps in funding for new technology companies, offering the possibility of resource allocation and transfer of administrative know-how.

- São Paulo Anjos: This private, nonprofit organization's mission is to bring together angel investors and entrepreneurs in emerging technology-based companies.

- $\quad$ Entrepreneur:This is a producer who initiates economic changes in society with innovations and, if necessary, "educates" consumers to use these innovations, which provokes new consumer desires that streamline the economy (Schumpeter, 1982).
- $\quad$ Expectations of FINEP and São Paulo Anjos agents: These codes were developed based on the following definition: expectation is the hope founded on promise, feasibility, or probability of entrepreneurs and financing agents.

The codes aid in understanding the relationships between those involved concerning venture capital investment in the processes of creation, development, and start-up of emerging technology-based companies - processes involving entrepreneurs needing financial contributions, FINEP, and SPA and its associates. As the arrows in Figure 4 indicate, venture capital is part of one of the types of financial support offered by FINEP, SPA and angel investors. As such, this form of investment causes the emergence or strengthening of technology-based start-ups. Thus, SPA plays an important role in bringing together angel investors and technology entrepreneurs and contributes positively to their increased technical, managerial, and human capacity. On the other hand, the venture capital provided by FINEP and SPA justifies that agents of these two organizations have the expectations described herein.

The analysis shows that FINEP agents' expectations vis-àvis entrepreneur are compliance with deadlines established by the institution, development of the elements specified in the approved project (prototype, product, etc.), generation of innovations that benefit society, and development of business management knowledge and practice. SPA agents' expectations are fulfillment of the stages established in the initial project and obtainment of business profitability consistent with the financial market investments. Additionally, SPA agents' expectations in relation to entrepreneurs who submit their projects are the entrepreneur's high motivation and passion in relation to the business - i.e. the entrepreneur must believe in the innovative project being presented to the SPA and its associates - work ethically and according to the law, and, lastly, maintain a very good relationship with SPA agents to achieve solid results.

\section{Conclusion}

Industrialized countries have difficulty sustaining economic leadership given the ongoing global technological dynamism. To maintain or seek leadership, a country needs a large number of companies that sustain a significant and continuous investment in R\&D, producing innovations that enable it to nurture competitiveness (Coutinho, 2004). Less industrialized countries experience a scarcity of financial and a macroeconomic instability that generally hinders investment, particularly regarding venture capital (Moraes et al., 20I0).

The creation, initial start-up, and development of technologybased companies as well as the technological development of a society require the establishment and maintenance of

ISSN: 07 I8-2724. (http://www.jotmi.org)

Journal of Technology Management \& Innovation (c) Universidad Alberto Hurtado, Facultad de Economía y Negocios. 
financial instruments that support technology-based SMEs and can offer venture capital conducive to generating innovation (Madill, Haines Jr and Riding, 2005, Ajagbe et al., 20I2). As such, each country pursues its particular solution to cope with the uncertainty that permeates the innovation process and, thus, scientific and technological development. In Brazil, venture capital activity is still at the embryonic stage. However, institutions such as FINEP and SPA are encouraging and investing in venture capital activities for start-up technologybased enterprises with growth potential and differentiated value for the market and for the technical and scientific development of the country.

According to studies by Gorgulho (1996) and Calvosa and Freitas (2008), in Brazil the limited experience in venture capital activities result, first, of the existence of an unfavorable macroeconomic environment characterized, among other factors, by instability and high remuneration rates for low-risk investments. Also of fundamental importance is the lack of a mature capital market and regulatory and fiscal mechanisms that encourage development of such activities. Within this context, this study investigated FINEP and SPA agents' expectations concerning venture capital investments in the process of creation, development, and start-up of technology-based SMEs.

We conclude that FINEP expectations are aimed at two points: the purposes of its investments and the investments it realizes. When FINEP selects projects for financial contributions, its analysts seek to ensure the projects contribute to the economic and social development of Brazil and are aligned with the policies of growth in strategic areas defined by the federal government. Among the strategic axes supported by FINEP and the federal government are agriculture and agribusiness, energy, oil and gas, health, defense, information technology, communication, and socio-environmental sustainability. This is the first filter in the selection process for projects to receive FINEP funding and, in fact, guides agents' expectations of the organization in such directions. SPA agent's expectations vis-à-vis entrepreneurs are that they show motivation and passion about their project, that they work within the ethical precepts of the law, and, lastly, that there be an excellent relationship between the parties, SPA associate investors and entrepreneurs for the project to achieve good results. One possibility that SPA agents keep in mind is that these entrepreneurs, supported financially, may become associated with the SPA and make investments in the future as well, creating a virtuous cycle for the promotion and creation of more new ventures.

In relation to the similarities between expectations of FINEP and SPA agents, we identify and conclude that both institutions expect that entrepreneurs benefiting from the financial resources will meet the deadlines and stages established in the initial projects for the creation, development, and startup of technology-based companies, act ethically, and foster technical and scientific development in the country. We also infer that venture capital is one of the elements that can leverage the development of a country, state, city, or region and that it can come from various sources, refundable or not, from public or private investors in order to stimulate the economy and growth of domestic industry.

The intention of private investors is to generate sources of wealth and development of businesses which can growth facing the globalized and highly competitive market. For the government, on the other hand, what is vitally important is the emergence of strong technology-based companies in key areas that contribute to the country's development. This emergence needs to be encouraged by the federal government on a larger scale for the country to achieve international competitiveness in science and technology and provide greater welfare to its population. 


\section{References}

AJAGBE, M. A., Long, C. S., Aslan, S. A., Ismail, K. (20I2). Investment in Technology-Based Small and Medium Sized Firms in Malaysia: Roles for Commercial Banks. International Journal of Research in Management \& Technology, 2 (2), I47-I53.

ASSOCIAÇÃO Nacional De Entidades Promotoras De Empreendimentos De Tecnologia AVANÇADAS (ANPROTEC). (2002). Glossário Dinâmico de Termos na Área de Tecnópolis, Parques Tecnológicos e Incubadoras de Empresas. Brasília: ANPROTEC.

BERTÉ, E. C. O. P., Rodrigues, L. C., Almeida, M. I. (2008). A Formulação de Estratégias para Pequenas Empresas de Base Tecnológica. Revista de Administração UFSM, Santa Maria, I (I), II6-I33.

BOSMA, N., Levie, J. (2010) Global Entreprenurship Monitor: 2009 Results. [S.I.]. London. http://www3.babson.edu/ ESHIP/research-publications/upload/GEM_2009_Global_ Report.pdf. [Accessed December 05, 20I0].

BOTELHO A. J., Didier, D., Rodriguez Y Rodriguez, M.V. (2006) Impulsionando o Take-off da Inovação no Brasil: O Investidor Anjo. $30^{\circ}$ Encontro da Anpad (Enanpad) Salvador - BA - Brasil, 23 a 27 de setembro. http://www.anpad.org.br/ enanpad/2006/dwn/enanpad2006-gctb-0483.pdf [Accessed January 05, 2010].

CALVOSA, M., Freitas, J. (2008). Angel Investor: empreendedorismo fomentado através de uma nova modalidade de investidor. Revista Cadernos de Administração, I (2), I-I8.

CARVAlHO, M. M., Machado, S. A., Pizysiezng, J., Filho, \& Rabechini, R., Jr. (2000). Fatores Críticos de Sucesso de Empresas de Base Tecnológica. Produto \& Produção, 4(n.esp.), 47-59.

COSTA, E. M. (2005). Financiando a Inovação nas Empresas (e inovando nas formas de financiamento). Parcerias Estratégicas, Brasília, 20, 987-999.

COUTINHO, P. L.A. (2004). Estratégia Tecnológica e Gestão da Inovação: uma estrutura analítica voltada para os administradores das empresas. Rio de Janeiro. 292. Tese de Doutorado. Universidade Federal do Rio de Janeiro.

EISENHARDT, K. M. (1989). Building Theories from Case Study Research. Academy of Management Review, I4 (4), 532-550.
ENDEVOUR. Capital de Risco. (2010). http://endeavorv5. isat.com.br/downloads/PPT/Workshop2006/ApresentacaoEndeavor0504.pdf [Accessed November 18, 2010].

FINANCIADORA De Estudos E Projetos (FINEP). (200I). Projeto Inovar: Ações e Resultados - Setembro de 2001. http://www.finep.gov.br/numeros_finep/relatorio_inovar/ relatorio_inovar.pdf [Accessed December 18, 2010].

FINANCIADORA De Estudos E Projetos (FINEP). (20I0). Marcos Históricos. http://www.finep.gov.br/o_que_e_a_ finep/a_empresa.asp? codSessaoOqueeFinep $=2$ [Accessed October 13, 20I0].

GLASER, B., Strauss, A. (1967). The Discovery of Ground Theory: Strategy of Qualitative Research. London: Wedenfeld and Nicholson.

GORGULHO, L. F. (1996). O Capital de Risco como Alternativa de Financiamento às Pequenas e Médias Empresas de Base Tecnológica: o caso do Contec /BNDES. 18I. Dissertação (Mestrado em Economia) - Universidade Federal do Rio de Janeiro, Rio de Janeiro.

INSTITUTO Brasileiro De Geografia E Estatística (IBGE). (2005). Pesquisa de Inovação Tecnológica. http://www.ibge. gov.br/home/estatistica/economia/industria/pintec/2005/ pintec2005.pdf. [Accessed October 13, 20I0].

LI, L., Qian, G., Qian, Z. (20I2).The Performance of Small and Medium-sized Technology-based Enterprises: do product diversity and international diversity matter? International Business Review, 2 I (5), 94I-956.

LIMA, E. (2005). Microdinâmicas da Difusão de Inovações entre Micro, Pequenas e Médias Empresas (previous version on internet: http://www.inf.furb.br/ dalfovo/EdmilsonLima). In: Pedro Paulo Hugo Wilhelm; Mohamed Amal. (Org.). Arranjos Produtivos Locais: Estratégias de Cooperação e Desenvolvimento. Blumenau: Nova Letra, 83-120.

LIMA, E. (20I0). Teorizando a partir de Dados Qualitativos em Administração. Pretexto, I I (I), p. 73-93.

LIMA, E. (20I2). Les Liens entre Représentations Entrepreneuriales et Vision Partagée : étude $d$ équipes de dirigeants de PME. Revue Internationale de Psychosociologie, I8, 199-225.

MADILL, J. J., Haines Jr, G. H., Riding, A. L. (2005). The Role of Angels in Technology SMEs: a link to venture capital.Venture Capital: an International Journal of Entrepreneurial Finance, 7(2), 107-129. 
MARKUSEN, A., Hall, P., Glasmeier, A. (1986). High-Tech America: the what, how, where and why of sunrise industries. Boston:Allen \& Unwin.

MARTIN, G., Staines, H. (1994). Managerial Competencies in Small Firms. Journal of Management Development, 13(7), 23-34.

MEYER, M.H., Roberts, E.b. (1988). Focusing Product Technology for Corporate Growth. Sloan Management Review, Massachusetts, 29, 7-16.

MENDES, G. H. S., Mecenas, D. S., Toledo, J. C. (2004). Caracterização da Gestão do Processo de Inovação em Empresas de Base Tecnológica de Pequeno e Médio Porte: estudo de casos em empresas residentes em uma incubadora de alta tecnologia. Anais do Simpósio de Gestão da Inovação Tecnológica, Curitiba, PR, Brasil, 23.

MILES, B. M., Huberman,A. M. (1994). Qualitative Data Analysis: an expanded sourcebook. 2 ed. Sage: Oaks, California.

MORAES, M. B., Lima, E. O., Lobosco, A. (20I I). Competências para Inovar em Pequenas e Médias Empresas Tecnológicas. Revista de Administração e Inovação, 8(4), 206-226. doi: 10.5773/rai.v8i4.894

MORAES, M. B., Melo, F. C. L., Oliveira, E. A. A. Q., Cabral, A. S. (20I0). Analysis of Technological Innovation Strategy for Small and Medium Companies of the Aeronautical Sector. Journal of Aerospace Technology and Management, 2 (2), 225- 236. doi: I0.5028/jatm.20I0.020254I0

MUHR, T. (1995) Atlas/ti, Release I.IE. In: Weitzman, E. A., Miles, M. B. Computer Programs for Qualitative Data Analysis. Thousand Oaks: Sage. 217-229.

ORGANISATION For Economic Co-Operation And Development - Oecd. (20II). Science, Technology and Industry Scoreboard 20II. Paris:Author.

ROTHWELL R., Dodgson M. (1989). Technology Strategies in Small and Medium sized firms. In: Dodgson, M. (Ed.). Technology strategy and the firm. London: Longman.

SANTOS, S. A., Rodrigues, F. Z., Dutra, I., Parejo, M. (2005). Empreendedorismo de Base Tecnológica: evolução e trajetória. Maringá: UNICORPORE.

SÃO Paulo Anjos (SPA). (20I3).A Seleção de Projetos. http:// www. saopauloanjos.com.br/conteudo.asp? pag $=2 \&$ id $=14$ [Accessed March 17, 2013].
SCHUMPETER, J. A. (1982). Os Economistas:Teoria do Desenvolvimento Econômico: uma investigação sobre lucros, capital, crédito, juro e o ciclo econômico. São Paulo: Abril Cultural.

SPENCER, M. (2003). International Strategy Formation in Small Canadian High-Technology Companies. Journal of International Entrepreneurship, I(3), 277-296.

WELSH, J.A.,White, J. F. (198I).A Small Business is not a Little Big Business. Harvard Business Review, 59(4), 18-32. 